\title{
The use of in situ hybridization in studies of viral disease
}

\author{
Adrienne L. Morey and Kenneth A. Fleming \\ University of Oxford, Nuffield Department of Pathology and Bacteriology, John \\ Radcliffe Hospital, Headington, Oxford OX3 9DU
}

\section{INTRODUCTION}

In situ hybridization has a number of features which make it particularly suitable for use in studies of viral disease. Not only can it confirm the presence of specific viral DNA or RNA sequences in a range of histological preparations, but by demonstrating the precise tissue, cellular and subcellular location of the virus it can correlate the presence of a virus with its pathological effects and provide insight into the mechanisms involved in virus-host cell interactions. Such information is necessarily lost when the more conventional technique of dot (filter) hybridization of extracted nucleic acid, or the more recently described polymerase chain reaction (PCR) are used to detect viral sequences. As well as localizing viral genomes in the episomal or integrated state, in situ detection of viral mRNA is possible. This can provide valuable information about the level of viral gene expression and sites of viral protein synthesis. In addition, in situ hybridization can be combined sequentially with immunohistological labelling of either cellular antigens (to identify unequivocally the cell types infected) or viral antigens (to determine whether viral nucleic acid is being translated into protein products), thus increasing the amount of information available from a given sample of tissue.

Although the great potential of in situ hybridization as a diagnostic and investigative tool in studies of viral disease was evident early in the history of this technique (Orth et al., 1970; McDougall et al., 1972), it is only relatively recently that technological and methodological advances have made possible the realization of this potential. The cloning of genetic material from most important DNA and RNA viruses has enabled the production of almost unlimited quantities of a wide variety of probes; in addition, the availability of sequence data on these viruses has made possible the construction of highly 
specific oligonucleotide probes. The commercial availability of an increasing range of probes has put in situ hybridization within reach of non-specialized laboratories. The development of non-isotopic labelling and detection systems has led to dramatic improvements in the speed and resolution of the technique, while reducing the costs and hazards associated with radioactively labelled probes. Initial problems with reduced sensitivity using non-isotopic probes have been largely overcome by continuing methodological refinements. Tissue digestion techniques adapted from immunohistochemistry have made in situ hybridization possible on formalin-fixed, paraffin-embedded tissue, thus making vast archives of stored material with good tissue morphology available for retrospective studies. These advances have led to a broadening of the possible applications of in situ hybridization, and an exponential increase in the number of laboratories using the technique as a research or diagnostic tool (Fleming, 1987; Grody et al., 1987; Hofler, 1987).

In order to highlight those areas in which in situ hybridization can provide unique insights into the process of viral infection, we have chosen to discuss the use of the technique in viral studies in terms of its particular strengths, rather than reviewing all possible applications. We have defined in situ hybridization as the use of labelled nucleic acid probes to detect complimentary sequences in tissue sections, cellular preparations, or chromosome spreads. Protocols involving the use of non-cellular preparations (such as filter and sandwich hybridizations) to detect viral genomes are not included, but have been described in previous reviews (Bornkamm et al., 1983; Maitland et al., 1987; Norval and Bingham, 1987). While we have focused on the use of in situ hybridization in the study of human viral diseases, it should be noted that the technique has been extensively employed in the study of viral infections in other species, both as animal models of human disease and in the context of veterinary medicine (e.g. Orth et al., 1970; Brahic et al., 1981; Brahic et al., 1984; Stowring et al., 1985; Peluso et al., 1985; Gendelman et al., 1986; Baskar et al., 1986; Jilbert et al., 1987; Alexandersen et al., 1987; Perlman et al., 1989; Lipkin et al., 1989). The technique has also been employed in analysis of insect-borne viruses (Ballinger et al., 1988) and plant viroids (Harders et al., 1989).

Specific applications of in situ hybridization in the context of viral disease fall into three main categories:

(i) as a diagnostic tool where other methods are slow or inadequate,

(ii) to investigate virus-host cell interactions (including the role of viruses in oncogenesis),

(iii) in studies of basic viral biology, including mechanisms of replication. 
Before reviewing these three categories, a number of general methodological points with relevance to viral studies should be made.

\subsection{Methodological considerations relevant to viral in situ hybridization}

\subsubsection{Types of probe}

The researcher aiming to become familiar with in situ hybridization techniques is faced with an increasing variety of different probe types, probe labelling strategies, hybridization protocols and detection systems (see Chapter 1, also reviews by Coghlan et al., 1985; Moench, 1987; Maitland et al., 1987; Grody et al., 1987; Norval and Bingham, 1987; Hofler, 1987; Myerson, 1988). The optimal strategy for each particular application will vary depending on the origin and preparation of the tissue being probed, and the nature and location of the target nucleic acid.

The greatest published experience is with double-stranded DNA probes, labelled with either radioactive or non-radioactive reporter molecules by nick translation or random priming techniques. The use of stable non-isotopic labels such as biotin has made possible the commercial availability of labelled double-stranded DNA probes for several viruses (Enzo Biochem; Life Technologies; Euro-Diagnostics). The production of single-stranded RNA riboprobes using specialized plasmid vectors containing dual RNA polymerase promoter sequences has introduced a new degree of flexibility to in situ hybridization studies; sense and antisense probes can be used to determine the polarity of the target nucleic acid, and have been especially useful in investigations of viral gene expression in latent infections. Unfortunately biotinylated nucleotides are not efficient substrates for the SP6 RNA polymerase, and thus most workers have employed isotopic labels for riboprobes; the development of alternative non-isotopic labelling strategies will undoubtedly be of major importance in broadening the range of applications of such probes. Advances in the technology for synthesizing oligonucleotides have made possible the preparation of short (20-60 base pair), single-stranded, customized DNA probes at relatively low cost. Based on sequence data, they can be designed to be "unique" for a particular strain of virus, or to contain sequences shared by a family of viruses. While eliminating the need for purification and cloning of viral nucleic acid, such probes suffer from limited sensitivity because of the low level of incorporation of reporter molecules and the usual requirement for 3' or 5' "end labelling". Labelling with non-isotopic markers is possible, however the use of cocktails of different oligonucleotides is sometimes necessary in order to achieve satisfactory sensitivity. A final method of probe production employs the polymerase chain reaction (PCR). This technique employs a heat stable DNA polymerase from Thermus aquati- 
cus (Taq polymerase) to amplify a chosen segment of DNA by many orders of magnitude. Labelled nucleotides (either isotopic or non-isotopic) can be directly incorporated into the amplified sequence, producing a highly specific probe with theoretically greater sensitivity than oligonucleotide probes. A technique for producing biotinylated hepatitis B virus probes using PCR has been developed in this laboratory (Lo et al., 1988), and studies are currently underway to extend this technique to other non-isotopic labels such as digoxigenin, and to optimize PCR-labelled probe characteristics for use in in situ hybridization.

\subsubsection{Probe labelling strategies}

The choice of probe label depends on the particular requirements of the investigation. While high energy emission isotopic probes (labelled with ${ }^{32} \mathrm{P}$ or ${ }^{125} \mathrm{I}$ ) are ideally suited to macroscopic studies of viral distribution in whole animal or organ sections, they give poor subcellular resolution compared to non-isotopic probes. Low energy isotopic probes (incorporating ${ }^{3} \mathrm{H}$ ) provide good resolution, but require long periods for autoradiographic detection. Probes labelled with ${ }^{35} \mathrm{~S}$ have recently gained popularity, providing a reasonable compromise between requirements for resolution, sensitivity and speed. An advantage of isotopic labelling is that it is possible, by grain counting, to quantitate the amount of bound probe. Recent methodological advances have improved the sensitivity of non-isotopic detection systems to provide comparable sensitivity with ${ }^{35}$ S-labelled probes, however quantification of target nucleic acid using non-isotopic systems is problematic. Non-isotopic protocols are generally more rapid than isotopic protocols, and being free from radiation hazards are potentially more useful as diagnostic assays in the general laboratory setting. The range of non-isotopic labels available is steadily increasing (see Chapter 1). Hybrids between labelled probe and target can be detected by histochemical or immunohistochemical means and visualized using fluorescent conjugates, a variety of coloured enzyme substrates, or colloidal gold. While fluorescent detection is sensitive and affords good resolution, it is generally unsuitable for use on tissue sections because of tissue autofluorescence, and has the additional disadvantage of fading over time. Chromogenic substrates provide a more permanent means of detecting hybridization signal, and substrates of different colours can be chosen as appropriate to allow counterstaining or multiple labelling of more than one nucleic acid target (see below). Colloidal gold has only recently been employed for non-isotopic labelling of viral sequences in tissue sections (Cubie and Norval, 1989; Morey et al., 1991a). It has the advantages of non-toxicity, highly localized signal and compatibility with standard haematoxylin/eosin staining (Figure 1).

If the viral genome under investigation is too large to be cloned in a single 


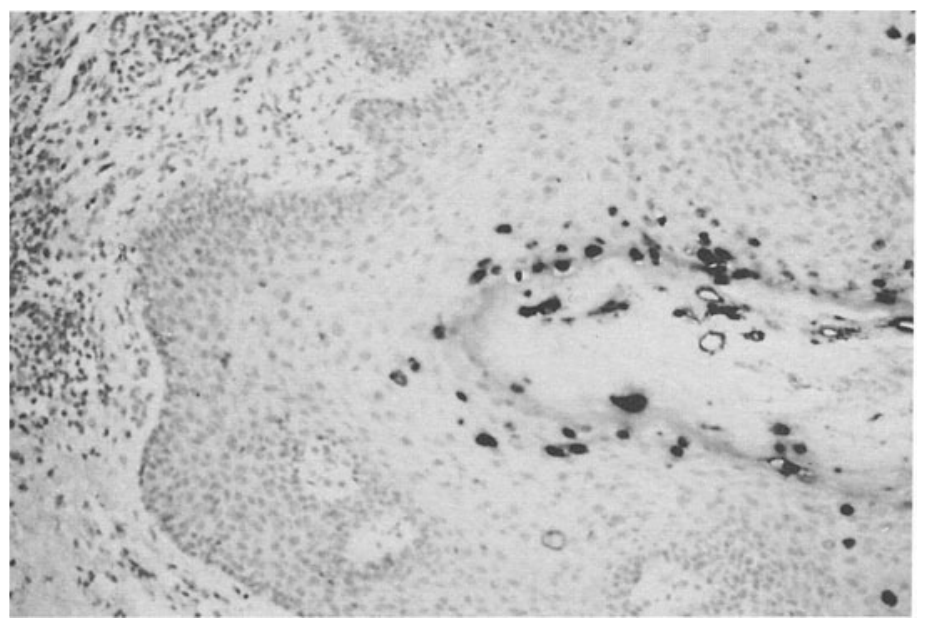

Figure 1 Formalin-fixed, paraffin embedded section of an anogenital condyloma shown to be positive for human papillomavirus type 6 using a digoxigenin labelled DNA probe detected by immunogold labelling with silver amplification. Haematoxylin and eosin counterstain. Infected cells in the upper layers of the epithelium appear black.

vector, probes to the different segments of the genome can be combined in order to maximize sensitivity. Unrelated viral probes can also be combined in a single hybridization reaction to screen for the presence of any one of the component viruses. If different reporter molecules are attached to different probes, simultaneous infection of a single cell by more than one virus can be detected. This was first shown using ${ }^{3} \mathrm{H}$ and ${ }^{35} \mathrm{~S}$ probes to measles and visna viruses and a two-colour microradioautographic detection system (Haase et al., 1985a), but has more recently been successfully used to detect human papillomavirus (HPV) and herpes simplex virus (HSV) in single cells using biotinolyted and haptenized probes with different enzymatic detection systems (Mullink et al., 1989a). Viral and human genomic DNA sequences have also been simultaneously detected with biotin and digoxigenin labelled probes using different coloured enzymatic substrates (Herrington et al., 1989; Morey et al., 1991a). Double DNA target detection can also be combined with prior immunohistological labelling of specific antigens to give triple colour detection of three different targets in a single cell (Morey et al., 1991a; Colour plate 4). Viral and human mRNA species have also been simultaneously detected using ${ }^{35} \mathrm{~S}$ and biotin labelled probes (Ozden et al., 1990). While the co-detection of viral genomes and viral or cellular mRNAs is a possibility, obligate differences in the in situ hybridization protocols for DNA and mRNA make such a combination currently suboptimal (unpublished observations). 


\subsubsection{Tissue digestion protocols}

Viral sequences have successfully been detected in chromosome spreads, cell smears, frozen sections, and fixed tissues embedded in both paraffin and plastic. An important consideration in all fixed tissues is the requirement for proteolytic "digestion" to remove protein cross-linking and render the target nucleic acid available for hybridization. A range of different agents have been used with variable effectiveness (Brigati et al., 1983; Burns et al., 1987; Burns et al., 1988; Naoumov et al., 1988a). It is our experience that when testing archival clinical samples, digestion protocols must be optimized for each particular block of tissue, as the amount of proteolytic digestion required will depend not only on the type and duration of fixation, but also on the origin and state of the tissue prior to fixation. We have found that pretreatment of slides with the adhesive 3-aminopropyltriethoxysilane (Burns et al., 1987) is crucial to ensure retention of sections during proteolytic digestion. In order to ensure that sufficient digestion has been performed and to provide an index of sensitivity, the use of an internal control is advisable. When probing routinely processed tissues for viral DNA, we also hybridize an adjacent section with probe pHY2.1 which detects a $2.12 \mathrm{~kb}$ sequence occurring approximately 2000 times on the long arm of the Y chromosome (Cooke et al., 1982). Between 100 and 200 highly homologous $2.0 \mathrm{~kb}$ sequences are also present elsewhere in the genome. Unless extremely high stringency conditions are used, the autosomal ("female") homologues of the Y repeat should be readily detectable as well as the characteristic spot associated with the $\mathrm{Y}$ chromosome (Burns et al., 1988); failure to do so usually indicates that more vigorous proteolytic digestion is required. While it could be argued that the degree of digestion necessary to reveal chromosomal sequences is probably greater than that required to detect "free" nuclear or cytoplasmic viral nucleic acid, such a control is particularly relevant when probing for integrated viruses, and we feel that this is still the most reliable method available of ensuring that reasonable confidence can be attached to a negative result. An alternative method for judging the sensitivity of a protocol involves the use of cell lines with known numbers of integrated viral sequences as standards (i.e. HeLa cells containing 10-50 copies of HPV18, or Raji cells containing 50-100 copies of Epstein-Barr virus). Such cells can only serve as a valid comparison, however, if they have been fixed and processed in an identical manner to the tissue under investigation. A further method of assessing the sensitivity of a protocol involves the use of routinely processed tissues from transgenic animals whose cells contain a known number of copies of a particular sequence. We have employed transgenic mice containing between 2 and 20 copies of the human alpha-1-antitrypsin gene per cell to assess the sensitivity of non-isotopic in situ hybridization using digoxigenin labelled DNA probes 
(Fleming et al., 1991). As few as 10 copies of a $1.3 \mathrm{~kb}$ sequence could be unequivocally detected, suggesting that the non-isotopic detection of lowcopy integrated viral sequences in formalin-fixed paraffin-embedded tissues should be possible.

\subsubsection{Stringency conditions}

Viruses which are related but not identical to the probe can be detected by altering the stringency conditions of the reaction (see Chapter 1, Bornkamm et al. (1983) and Myerson (1988) for discussions of stringency calculation). Under conditions of low stringency, nucleic acid sequences with a degree of mismatch can hybridize. This finding has been employed in the detection of new viral strains and classification of related viruses, however sequence homologies also exist between parts of the human genome and numerous viruses, which under inappropriate stringency conditions can lead to false positive results. Conversely, the use of excessively high stringency conditions will lead to loss of sensitivity. It is thus important that stringency conditions be carefully calculated and applied in order to suit the particular situation under investigation.

\subsubsection{Further important methodological considerations}

Further important methodological considerations relate to problems of artefactual probe binding and non-specific background signal. These can result from a variety of factors both intrinsic to the hybridization protocol, and intrinsic to the tissue under study (see Myerson, 1988). The most intransigent cause of background in our experience of non-isotopic in situ hybridization using biotinylated probes is the presence of endogenous biotin in "hypermetabolic" tissues such as liver, kidney and pancreas. This endogenous biotin is bound by avidin or anti-biotin antibodies employed in probe detection, and can lead to highly deceptive false positive signals. Although some authors report success in blocking or removing endogenous biotin (Grody et al., 1987; Naoumov et al., 1988a) we have found that none of these methods enable reliable and reproducible detection of low copy viral genomes in these tissues. For that reason this laboratory is currently concentrating on the development of protocols employing alternative non-isotopic labels such as digoxigenin (Fleming et al., 1991; Morey et al., 1991b; Figure 2).

\subsubsection{Controls}

The use of appropriate positive and negative controls is crucial to the success and reliability of in situ hybridization as a diagnostic or investigative tool. If it is to assume even a minor role in routine laboratory diagnosis of viral infections (where decisions on patient management will depend on the result), it is imperative that reliable controls are employed. Positive controls should in- 


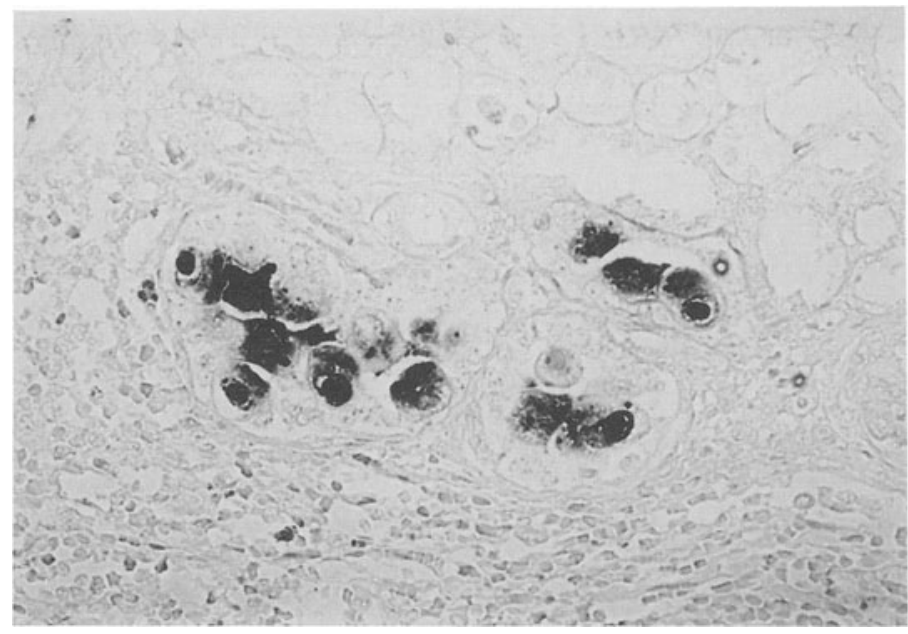

Figure 2 Cytomegalovirus DNA localised within the renal tubules in a case of fetal CMV infection. The DNA probe was nick-translated with digoxigenin and detected with an anti-digoxigenin alkaline phosphatase conjugate and NBT-BCIP chromogenic substrate. CMV DNA is seen in both nuclei and cytoplasm of cytomegalic epithelial cells.

clude tissues known to be positive for the virus using other means (but processed and tested in the same manner as the tissue under investigation) and general marker probes which can control for the efficiency of the hybridization reaction on each occasion (such as probes for the $\mathrm{Y}$ repeat or other high-copy genomic sequences). Negative controls include the use of labelled vector sequences without the viral insert, non-related similarly-labelled probes, opposite sense strand probes (if riboprobes are used) and the use of tissues reliably known to be negative for the virus. DNAse and RNAse digestions should also be performed in order to verify the identity of the target nucleic acid species being detected. In cases where there is any doubt as to the specificity of the reaction it is necessary to confirm the identity of the viral nucleic acid using dot-blot hybridization or other methods such as the polymerase chain reaction (Salimans et al., 1989; Pezella et al., 1989).

\section{DIAGNOSTIC APPLICATIONS}

The use of in situ hybridization in viral diagnosis is especially relevant for situations in which the virus cannot be easily or rapidly detected by other means. This includes viruses which grow insufficiently or not at all in cell culture (possibly requiring specific host cell factors which are absent in standard cell lines), and those which escape detection by immunological 
methods. This may be due to protein products which are antigenically variable, or synthesized at levels below the threshold for detection by serology or immunohistology. The latter situation frequently arises in clinically inapparent "latent" and "slow" infections. Even if antigen production does occur, and appropriate antibodies are available, in cases where only fixed tissue is available immunohistological studies may be unsuccessful due to masking or destruction of the antigenic determinants. Nucleic acids appear to be largely unaffected by fixation however, and are readily rendered accessible for study by proteolytic digestion. In situ hybridization can be an effective diagnostic tool where rapid diagnosis is required, or where the state of the tissue precludes other forms of investigation (for example because of autolysis, or contamination by bacteria or other viruses). It also can be used to quantitate absolute numbers of infected cells, and to monitor the effects of antiviral treatment at the tissue level. Low stringency hybridization using broadly reacting probes from conserved regions of viral genomes can be used to detect related viruses which may be overlooked by immunohistochemical methods. A diagnostic application which is unique to in situ hybridization is the ability to identify viral subtypes (as with the various types of human papillomavirus) in relationship to associated histopathological abnormalities. The technique has also been applied to retrospective searches for viral involvement in a variety of diseases of unknown aetiology.

\subsection{Sensitivity}

An important feature of in situ hybridization is its sensitivity in instances where only a small proportion of cells are infected; this may occur in early, focal, latent or resolving infections. Examination of such cases using tissue extraction methods such as dot hybridization is likely to be negative (due to "dilution" of the target viral sequences by cellular nucleic acid), electron microscopic searches for intact viral particles have a limited chance of success, and the extent of antigen expression may be sufficiently reduced as to be below the threshold for detection. In such cases, in situ hybridization (which can theoretically detect the presence of specific hybridization signal in a single cell per section) may enable a diagnosis to be made. An example of such sensitivity was provided by Brahic et al. (1981) in an early study on visna (a slow virus which causes progressive neurological deterioration in sheep); in choroid plexus cells from experimentally infected sheep, viral antigen was almost undetectable, however by in situ hybridization with radiolabelled probe, visna RNA and proviral DNA were detected in between 1-3\% of cells. While the polymerase chain reaction is generally believed to be an even more sensitive method of viral detection in such cases of low-level infection, standard 
protocols achieve this at the expense of histological localization of the virus, and the presence of "inhibitors" in paraffin-embedded material can limit the sensitivity of the technique in routinely processed specimens. Successful combination of the amplifying power of PCR with the localizing ability of in situ hybridization has only recently been reported (Haase et al., 1990). The antithetical demands of PCR (for good access to target) and in situ hybridization (for retention of nucleic acid in cellular structures) were satisfied by the use of multiple primer pairs to amplify overlapping segments of DNA. The cohesive termini of the amplified fragments enabled the formation of large covalently-linked segments which were effectively retained within the cell. Applied to the detection of visna virus DNA in experimentally infected cultured cells, the "in situ amplification" technique led to 200 -fold improvement in sensitivity (Haase et al., 1990). While the technique has not, as yet, been successfully applied to formalin-fixed, paraffin embedded tissues, it obviously holds considerable promise for use in investigations into the pathogenesis of viral infections. In particular, the amplification of target within single cells is inherently less likely to be affected by "contamination" by exogenous nucleic acids, a major problem with the use of the polymerase chain reaction in solution.

\subsection{Rapidity}

Because of the relative rapidity of modern in situ hybridization techniques compared to traditional viral culture, in situ hybridization (especially using non-isotopic probes) has been advocated as a diagnostic tool in certain cases where patient management is dependent on rapid diagnosis. This is particularly pertinent now that anti-viral chemotherapy is becoming a clinical reality. The diagnosis of herpes simplex virus (HSV) encephalitis using cells obtained from the cerebrospinal fluid (Bamborschke et al., 1990) is an example of such an application. Viral DNA was detectable in cytospun preparations of these cells at the time of onset of symptoms and before the beginning of intrathecal IgG synthesis. A second example involves the use of in situ hybridization to determine whether cytomegalovirus (CMV) infection is responsible for hepatic dysfunction after liver transplantation. Infection with $\mathrm{CMV}$ frequently complicates the clinical course of patients on immunosuppressive treatment, and may be directly responsible for graft failure, however it is vitally important to differentiate infection from rejection of a transplanted organ. Immunosuppressed patients may lack the usual serological markers of infection, or have co-existent but clinically insignificant reactivation of previous infection. Direct demonstration of CMV DNA in areas of inflammation, however, provides strong evidence that a case of post-transplant hepatitis is due to the virus 
(Naoumov et al., 1988b; Masih et al., 1988). A diagnosis can be obtained in less than 24 hours (as opposed to viral culture which may take weeks to show a cytopathic effect), thus providing the opportunity for early adjustment of management. The recent availability of specific oligonucleotide probes for the detection of mRNA from the abundantly transcribed Immediate Early and Early CMV genes (British Biotechnology Ltd.) holds promise for rapid diagnosis at even earlier stages of infection.

\subsection{Diagnosis of non-culturable viruses}

In situ hybridization has proved a particularly useful tool in the diagnosis and assessment of infections caused by viruses with stringent host cell requirements which do not permit the virus to replicate effectively in continuous cell-line culture systems. Two such viruses which have been studied in this laboratory are the human papilloma virus (HPV) and the human parvovirus (B19).

The human papilloma virus (HPV) propagates effectively only in terminally differentiated keratinocytes. Standard cell lines (which by nature are relatively undifferentiated) cannot support the growth of this virus. Prior to the advent of recombinant DNA technology HPV variants were suspected on clinical grounds, however cloning and sequencing techniques have now enabled the identification of over 60 different subtypes. Antibody to the highly conserved capsid protein allows immunohistological detection of productively infected cells, but examination of viral nucleic acid remains the only effective method of diagnosing latent infection. In infected epithelia, the accumulation of viral DNA and the expression of antigen both correlate with the degree of keratinization, though cells positive for HPV DNA exceed the number containing capsid antigen and are found at lower levels of the epithelium (Beckmann $e t$ al., 1985). Though efforts are underway to produce type-specific monoclonal antibodies (Patel et al., 1989), DNA hybridization using type-specific nucleic acid probes remains the only reliable means of differentiating the vast majority of HPV types. If low stringency conditions are employed in the hybridization reaction, cross hybridization between various types can occur. Such cross hybridization is proportional to the degree of similarity in the base pair arrangement of the target nucleic acid and the probe, and is frequently seen between types 6 and 11 which share a high degree of sequence homology. If hybridization and washing are performed under conditions of sufficiently high stringency however, positive identification of the particular type present in a given tissue is usually possible (Herrington et al., 1990). This is of some importance as a large body of epidemiological evidence suggests that certain papillomavirus types are associated with infection at particular anatomical 
sites, and with the development of various epithelial dysplasias and neoplasias (reviewed by Syrjänen, 1987). Common skin warts are usually due to infection with HPV types 1 to 4 , while types $6,11,16$ and 18 are found in anogenital lesions and are presumed to be sexually transmitted. Types 6 and 11 have been generally associated with benign condylomas and low grade dysplasias, but types 16 and 18 (as well as the less common types 31,33 and 35) have been more frequently found in cases of severe genital dysplasia and cervical carcinoma. While these associations are far from absolute, and an aetiological role for the virus in the production of malignancy has not been proven, a large number of researchers have used in situ hybridization techniques to confirm the findings obtained by other methods and to investigate further the role of various HPV subtypes in a wide variety of epithelial lesions (e.g. Beckmann et al., 1985; Burns et al., 1987; Beckmann et al., 1989; Terry et al., 1989).

High stringency in situ hybridization has been employed in this laboratory in a study of HPV types in anogenital warts in children (Padel et al., 1990). As genital HPV infection is a sexually transmitted disease in adults, it has been suggested that the presence of genital warts in a child is sufficient grounds for investigating that child as a possible victim of sexual abuse. It has been previously reported that genital warts in children are almost exclusively associated with the adult "genital" types $(6,11,16$ and18)(Vallejos et al., 1987). Results from this laboratory do not support that finding. Using type-specific double stranded DNA probes labelled with biotin and an avidin-alkaline phosphatase detection system, it was found that genital warts from 6 out of 17 children examined contained "skin" HPV types ( 2 or 3 ). In two cases, warts containing virus of the same type were present on the child's hands, raising the possibility of self-inoculation as the route of viral transmission. The appearance and site of the anogenital warts did not correlate with HPV type. These findings have important implications, especially on consideration of the problems associated with an incorrect diagnosis of sexual abuse.

The human parvovirus (B19) has recently been shown to be an important and widespread human pathogen (reviewed by Goldfarb, 1989). The causative agent of erythema infectiosum, the virus has also been shown to be the major cause of aplastic crises in patients with chronic haemolytic anaemia. It is capable of causing chronic bone marrow dysfunction in the immunosuppressed, and infection during pregnancy can lead to fetal hydrops and stillbirth. Because of requirements for as yet unspecified host cell factors, the human parvovirus shows a high degree of target cell specificity, with a particular predilection for red blood cell precursors. Though the virus has been propagated in short term haemopoietic cell suspension culture, it has not been successfully grown in continuous culture.

We have used in situ hybridization with non-isotopic probes to diagnose 


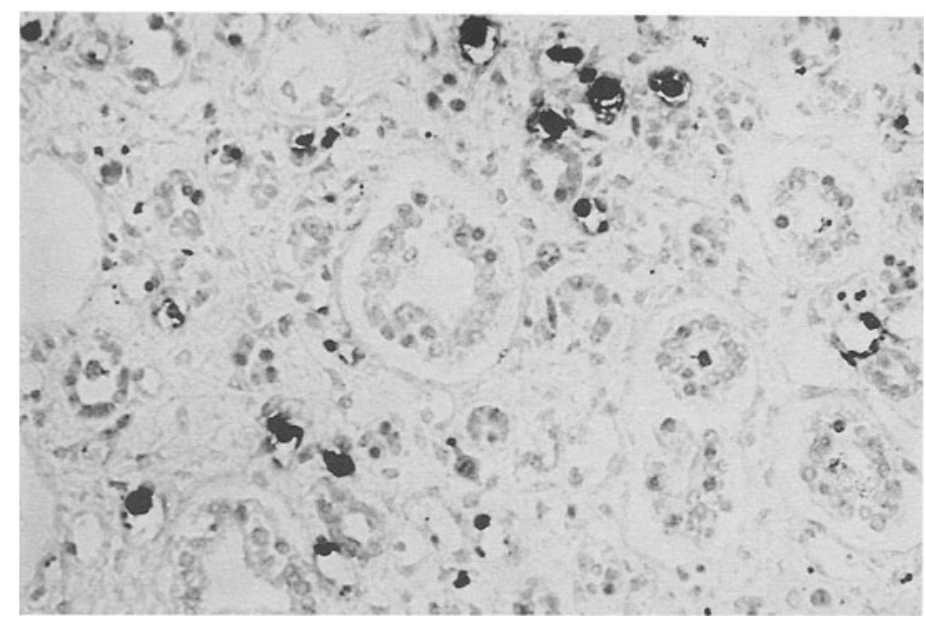

Figure 3 Parvovirus B19 infected cells in small vessels in the kidney of a fetus with non-immune hydrops. Digoxigenin labelled DNA probe detected with anti-digoxigenin alkaline phosphatase conjugate and NBT-BCIP chromogenic substrate.

human parvovirus infection in archival material from stillborn fetuses (Porter et al., 1988; Morey et al., 1991b). Tissue from such cases is frequently difficult to examine using standard techniques because of maceration and autolytic damage, however viral DNA is relatively resistant to degradation and can be readily demonstrated in infected cells within fetal tissues (Figure 3). Parvovirus DNA was detected in routinely processed tissues from 10 out of 37 cases of otherwise unexplained non-immune fetal hydrops, accounting for $8 \%$ of all cases of non-immune hydrops examined over a 16 year period. Cells containing parvoviral DNA were distributed within blood vessels and alveoli, the number of positive cells exceeding the number of cells found to contain typical viral inclusions on routine light microscopy. The question of target cell specificity of human parvovirus in these cases has also been examined by a combination of immunohistology for cellular antigens and in situ hybridization for parvoviral DNA (see below).

\subsection{Diagnosis of latent or slow virus infections}

In situ hybridization remains the only effective method of diagnosing latent infections in a histological context, as viral protein production is often not only insufficient to stimulate an effective immune response, but also below the threshold for detection by immunological techniques. An example of the application of in situ hybridization techniques to the investigation of latent 
viral disease which has important and disturbing implications for public health planning includes the detection of human immunodeficiency virus (HIV-I) nucleic acid in a small minority of peripheral blood mononuclear cells of patients who were "at risk" of infection but seronegative at the time of the study (Pezella et al., 1989). Additional examples include the localization of varicella zoster virus (VZ) and herpes simplex virus (HSV) transcripts in the neural ganglia of patients without evidence of overt disease (Croen et al., 1988), and the detection of measles virus genomes in brain biopsies of patients with subacute sclerosing panencephalitis (SSPE) (Haase et al., 1985b). In situ hybridization has also been used in studying animal models of latent and slow viral disease (e.g. Brahic et al., 1981, 1984; Peluso et al., 1985; Stowring et al., 1985; Gendelman et al., 1986), providing a powerful means of investigating the mechanisms behind the establishment and maintenance of latent infection (see below).

\subsection{Search for viral involvement in cryptogenic disease}

The realization that viral infection can occur (and be detected by in situ hybridization) in the absence of any of the conventional markers of viral disease, has encouraged numerous groups to use the technique to search retrospectively for viral involvement in a range of diseases of unknown aetiology. Many of these investigations have produced a negative result; they include studies which have failed to demonstrate a significant relationship between adenovirus infection and follicular bronchiectasis (Hogg et al., 1989), or between CMV and Kaposi's sarcoma (Grody et al., 1988). Other studies have detected specific viral nucleic acid in an equivalent or greater number of "control" than "affected" subjects. They include investigations into the role of Epstein Barr virus (EBV) in Sjögren's syndrome (Venables et al., 1989) and of measles virus in multiple sclerosis (Haase et al., 1984). Such findings obviously argue against a simple causal relationship between the particular viral infection and the disease in question, and demonstrate that humans may normally be host to a variety of ubiquitous viral genomes without stimulation of an immune response or apparent evidence of disease. The possibility remains that pathological changes are brought about by an atypical host response to the presence of a common infection.

Of particular interest however, are several studies which have suggested a significant association between the presence of viral genomes and the occurrence of disease. They include studies which have correlated the presence of HSV and CMV residues with atheromatous change in arterial walls (Benditt et al., 1983; Yamashiroya et al., 1988) - a finding given additional significance by the known association of Marek's disease virus (a herpesvirus) and the 
production of atheroma in birds - and the demonstration of CMV nucleic acid in pancreatic tissue from a subset of patients with non-insulin dependent diabetes mellitus (Lohr et al., 1990). In the latter study, the hybridization signal was localized primarily to the islets of Langerhans, but was not associated with any morphological abnormality or evidence of inflammation. Such preliminary findings obviously require further confirmation and the precise significance of the presence of these viral sequences remains to be determined, however in situ hybridization would seem to be the technique best suited to explore such questions.

\section{IN SITU HYBRIDIZATION IN THE STUDY OF VIRUS-HOST CELL INTERACTIONS}

In situ hybridization provides a versatile method of investigating virus-host interactions at every level; from whole animal studies of organ involvement with a particular virus, to analysis of sites of viral integration into host cell chromosomes. The technique has provided considerable insight into the pathogenesis of disease due to certain viral infections by allowing positive identification and characterization of the cell types involved. This has led to a re-evaluation of the mechanisms of spread of certain viruses through the body and to a better understanding of the role of the immune system (as opposed to direct viral cytopathic effect) in the resultant tissue damage. In situ hybridization studies have provided some unique insights into the process of latent infection and are assuming a significant role in the study of virus-related tumours.

\subsection{Identification of host cells and mechanisms of viral spread}

A variety of ingenious techniques have been evolved to enable the study of viruses at the whole animal or organ level. Most have involved cutting thick sections onto some form of adherent tape, then detecting viral nucleic acid using high energy radiolabelled probes (see review by Lipkin et al., 1990). For such applications, detailed resolution is not required, and a very satisfactory picture of the pattern of viral involvement at the macroscopic level can be obtained. Such macroscopic hybridization techniques can be useful to determine whether infection is diffuse or localized, to follow the anatomical distribution of a virus over the course of an infection, and to guide the choice of material for microscopic studies. Examples of the application of this concept include detection of visna virus in the paraventricular areas of the sheep brain (Haase et al., 1985c), localization of ground squirrel hepatitis virus to the liver 
in the chipmunk (Lipkin et al., 1990), and visualization of yellow fever virus in the abdominal fat body of infected mosquitoes (Ballinger et al., 1988).

It is at the tissue level, however, that in situ hybridization has found its widest application. The technique has been instrumental in identifying the host cell type and mode of spread in a wide range of viral infections. For example, peripheral blood leukocytes have been found to play a role in the spread of hepatitis B virus (HBV) (Hadchouel et al., 1988), CMV (Turtinen et al., 1987) and HIV-I (Pezzella et al., 1989). The affected cells in progressive multifocal leucoencephalopathy (PMLE), a demyelinating condition associated with reactivation of latent $\mathrm{JC}$ papovavirus in immunosuppressed patients, have been shown to be oligodendrocytes and astrocytes (Aksamit et al., 1985). In fetal and placental tissue removed from HIV-positive pregnant women at 8 weeks gestation, HIV-I nucleic acid has been detected in maternal decidual lymphocytes, villous trophoblast and Hofbauer cells, villous capillary endothelium and embryonic blood cell precursors (Lewis et al., 1990), suggesting a pathway for cell-to-cell transmission of the virus to the fetus and confirming that fetal infection can occur early in pregnancy. Demonstration of human herpes virus 6(HHV-6) in submandibular salivary gland tissue (Fox et al., 1990) supports the hypothesis that this virus may persist in the salivary glands and be transmitted by saliva. In situ hybridization has also been used extensively to study mechanisms of viral spread in animal models. For example, transynaptic neuronal spread has been shown be involved in the entry of murine hepatitis virus into the CNS of experimentally infected mice (Perlman et al., 1989) and evidence for venereal transmission of murine CMV was provided by the detection of viral nucleic acid in spermatocytes (Baskar et al., 1986). Replication of the duck hepatitis $B$ virus has been found to occur in pancreatic islet cells as well as in hepatocytes (Jilbert et al., 1987). Strand-specific probes have proved very useful in studies of Aleutian mink disease parvovirus infection (Alexandersen et al., 1987); because this parvovirus encapsidates single-stranded DNA of only one polarity as the virion genome, a probe of opposite polarity to the genome will detect both virions and double-stranded replicative intermediates, while a probe of the same polarity as the genome will hybridize only to replicative form DNA. The use of such probes has enabled the differentiation of cells supporting viral replication from cells that have merely sequestered the virus, and has shown that alveolar lining cells are the major site of viral replication in infected newborn mink (Alexandersen $e t$ al., 1987).

Studies on several viruses have indicated that the number of cells containing viral nucleic acid by in situ hybridization exceeds the number of cells showing morphological evidence of infection, indicating that appearances under light microscopy after routine staining can give a misleading impression of the 
extent of infection. This has been a consistent finding in studies of CMV infection in many different organs (Myerson et al., 1984; McDougall et al., 1986; Naoumov et al., 1988b; Porter et al., 1990), and a similar pattern of infection with human parvovirus B19 was seen in this laboratory (Porter et al., 1988). In cases where tissue preservation is not ideal or a heterogeneous cell population is present, in situ hybridization for viral nucleic acid can be combined with immunohistology for cellular antigens to allow unequivocal identification of infected cell types. This combination was first reported in a study on the slow virus visna in sheep (Stowring et al., 1985). Using a ${ }^{3} \mathrm{H}$ labelled probe for visna RNA and cell-type specific antisera detected by the immunoperoxidase method, infected cells in the brain were identified as oligodendrocytes. A similar technique was used to demonstrate that visna virus can infect mononuclear-phagocytic cells, the extent of viral replication being dependent on the degree of differentiation toward the macrophage phenotype (Gendelman et al., 1986). It was also employed to demonstrate that HIV-I was mainly found within macrophages in the central nervous system of patients with the acquired immunodeficiency syndrome (Koening et al., 1986; Eilbott et al., 1989). In a variation on this protocol, Vaseux et al. (1990) have combined immunolabelling for HIV-I antigen with in situ hybridization for JC papovavirus in brain tissue from AIDS patients with PMLE and severe HIV-I encephalitis. They were able to show that different cell populations were affected by the two viruses, but postulated that the encephalitis had spread via the recruitment of HIV-I infected macrophages into areas of JC-induced demyelination. Non-isotopic variants of the double-labelling technique using biotinylated probes and immunoperoxidase detection of antigens have recently been used in frozen sections or cultured cells to detect HPV in cytokeratinpositive cells and CMV in vimentin-positive cells (Mullink et al., 1989b; van der Loos et al., 1989). Most authors have advised performing immunolabelling first, though if the antigen is heat stable it may in some instances be preferable to perform the in situ hybridization first (Brahic and Haase, 1989).

Combined non-isotopic protocols suitable for use on paraffin-embedded material employing immunohistology for specific cellular antigens using the alkaline phosphatase-anti-alkaline phosphatase (APAAP) method (Cordell et al., 1984) and biotin- or digoxigenin-labelled probes for viral nucleic acid have been developed in this laboratory (Porter et al., 1990; Morey et al., 1991b). The APAAP method is generally recognized to be more sensitive than the immunoperoxidase labelling, and can be used prior to routine in situ hybridization without alteration to either technique or any additional steps between them. The use of this double-labelling technique has enabled positive identification of infected host cells in cases of human fetal parvovirus infection (Porter et al., 1990; Morey et al., 1991b). This had been difficult with standard 
counterstains because of the poor state of preservation of the tissues. Although tissue autolysis can adversely affect the expression of various cell surface and cytoskeletal antigens, judicious selection of antibodies can minimize these effects. We found that while the majority of cells containing parvovirus DNA were of erythroid lineage, hybridization signal was also found within numerous cells labelled as mononuclear-phagocytes (Colour plate 5), and within some myocardial cells labelled with an antibody to desmin. This suggests that the heart failure and hydrops in infected fetuses may not be due to anaemia alone, but may also reflect direct damage to the myocardium.

We have also employed combined immunohistology and in situ hybridization using digoxigenin labelled probes to investigate the host cell specificity of parvovirus in a short term haemopoietic cell suspension culture system (Morey et al., 1991c). Evidence of viral replication was found only in cells labelling with erythroid markers, and the pattern of distribution of the virus was dependent on the stage of maturation of the cell. The disruptive effect of infection on the host cell chromatin was demonstrated by combining double in situ hybridization (a digoxigenin labelled probe for whole human DNA together with a biotin labelled probe for parvovirus visualized using different enzymatic substrates) with immunolabelling of cell type specific antigens, giving triple colour detection of three specific targets in a single cell (Morey et al., 1991a: Colour plate 4)

\subsection{Viral gene expression and mechanisms of disease}

While numerous studies have compared sensitivity of immunohistological detection of viral antigen with labelling of viral nucleic acid using in situ hybridization, a more useful technique involves combining the protocols to enable the detection of viral genes or mRNA and their products in single cells. The relationship between the presence of viral nucleic acid and the expression of viral antigen has been investigated using combined protocols for viruses including HBV (Blum et al., 1984), Theilers murine encephalitis virus (Brahic et al., 1984), visna (Gendelman et al., 1985), measles (Gendelman et al., 1985), HPV (Mullink et al., 1989b; Cubie and Norval, 1989), HSV (Kennedy et al., 1988), hepatitis delta virus (Negro et al., 1989) and CMV (Wolber and Lloyd, 1988; van der Loos et al., 1989; Porter et al., 1990). While one group has reported that $\mathrm{CMV}$ antigen detection is unaffected by a preceding hybridization procedure (Wolber and Lloyd, 1988), most groups have concluded that it is prudent to perform immunohistological staining prior to in situ hybridization, in case denaturing temperatures adversely affect the antigen. A consistent finding in many of these combined studies is the demonstration of viral genomes in a greater proportion of cells than contain viral antigen. Such 
results can provide important insights into the relationship between viral infection, antigen expression and the presence of pathological changes. For example, the absence of protein may identify a point of blockade in the viral life cycle, while an abundance of protein products in a cell has important implications for the stimulation of an immune response.

Combined labelling procedures have been particularly useful in studies of latent viral infections. Double labelling for viral genes and antigens has been used extensively by Haase and co-workers to support the thesis that "persistent" infections are associated with restricted viral gene expression which enables the virus to escape detection by the immune system for prolonged periods (Haase, 1986; Brahic and Haase, 1989 for reviews). A low level of antigen production was also postulated to be important for the spread of visna virus through the body of experimentally infected sheep; low copy visna genomes were found in monocytes in the cerebrospinal fluid, despite the presence of neutralizing antibody (Peluso et al., 1985). It was suggested that the low level of viral gene expression in these cells enabled them to evade immune attack while disseminating the virus (the "Trojan Horse" theory). A similar mechanism was proposed for the persistence of $\mathrm{HBV}$ in cases of chronic active hepatitis; most hepatocytes found to contain HBV DNA did not express hepatitis B core antigen (Blum et al., 1984), thus an immune response directed against the antigen would be ineffective in eradicating the virus. Interestingly, in both chronic HBV infection (Blum et al., 1984) and chronic hepatitis delta infection (Negro et al., 1989), cells undergoing degenerative change did not appear to contain viral antigen and/or viral nucleic acid, though infected cells were found adjacent to foci of inflammation. This supports the possibility that the viral infection may have initiated an autoimmune process which was responsible for the observed tissue damage.

As a virus may cause disturbance by inducing or repressing the transcription of certain host genes, the ability to directly assess the effects of viral infection on host cell nucleic acid metabolism would of obvious benefit. Using a biotin labelled probe for Theiler's disease murine picornavirus mRNA and a ${ }^{35} \mathrm{~S}$ labelled probe for $\beta$-actin mRNA, Ozden et al. (1990) have recently co-detected viral and cellular mRNAs in single infected cultured cells. While in that study no obvious difference was seen in the expression of the b-actin gene between infected and non-infected cells, the technique has considerable potential for investigating the effects of infection on cellular gene transcription, especially when only a subpopulation of cells are affected.

The mechanisms behind the maintenance of latent infection of neural tissue by herpes simplex virus (HSV) have been extensively investigated using strand-specific probes for particular RNA transcripts, the amount of latent DNA itself being insufficient for detection by current in situ hybridization 
protocols. Studies on neural ganglia from a number of species including humans have demonstrated that latent infection is confined to neurons. It is associated with the expression of a single family of "latency associated transcripts" which map to the region of the viral genome coding for the immediate early protein (ICPO), but which unexpectedly are complementary to ICPO mRNA, suggesting a possible inhibitory role (see review by Stevens, 1989). The precise role of these novel transcripts in the maintenance of, or reactivation from, the latent state is still under investigation. By contrast, latent infection with varicella zoster virus (VZV) has been shown to involve nonneuronal cells, with multiple regions of the genome being expressed (Croen et al., 1988). This finding may underlie the different clinical features of disease produced by these viruses following reactivation. Further application of techniques for investigating the expression of particular genes at the cellular level will undoubtedly provide insight into the mechanisms associated with latent infection by many other viruses.

\subsection{Viral involvement in tumourigenesis}

Members of several viral families have been epidemiologically associated with the development of tumours. While simple causal associations are difficult to make, in situ hybridization has proved a very useful tool for investigating the relationship between viral infection and neoplastic change at the tissue level. For example, the technique has been used to identify various types of papillomavirus in a wide range of malignant and pre-malignant epithelial lesions in humans and other species (Milde and Loning, 1986; Syrjänen et al., 1988; Beckman et al., 1989; reviews by Syrjänen, 1987; Crum and Roche, 1990). The ability to detect low levels of viral DNA in dysplastic, less differentiated cells which do not express viral antigen is a major advantage of the technique. HPV has been detected not only in primary lesions, but also in metastatic deposits of cervical carcinoma in distant lymph nodes (Lewandowski $e$ t al., 1990). Epstein Barr virus genomes have been detected in malignant cells in biopsies of nasopharyngeal carcinoma (Hawkins et al., 1990) and several types of lymphoproliferative lesions including Hodgkin's and non-Hodgkin's lymphoma (Hamilton-Dutoit et al., 1989; Weiss et al., 1989), T cell lymphoma (Jones et al., 1988) and hairy cell leukaemia (Wolf et al., 1990), the association of EBV with lymphoproliferative lesions being especially common in immunosuppressed patients. The detection of hepatitis B virus DNA in both surface antigen-positive and surface antigen-negative patients with hepatocellular carcinoma has been reported (Brambilla et al., 1986).

A major advantage of using in situ hybridization in such studies is that it enables correlation of viral presence with the degree of cellular dysplasia, and 
permits investigation of abnormalities of cellular function consequent upon infection. For example, in situ hybridization has been combined with immunohistological studies to determine the relationship between viral infection and the loss of normal cellular differentiation characteristics. Differences in the pattern of cytokeratin expression between dysplastic and non-dysplastic cervical lesions associated with HPV infection have been postulated to reflect transformation of the cells by the virus (Syrjänen et al., 1988). Protocols enabling the differential detection of various HPV RNA transcripts in precancerous lesions (Crum et al., 1988) may provide significant insights into the role of certain transcripts in initiation of neoplastic change.

Some early in situ studies suggested that herpes simplex virus (HSV) RNA may be present in a considerable proportion of cervical cancers and precancers (McDougall et al., 1980; Maitland et al., 1981). While recent attention has been focused on the role of human papillomavirus in such lesions, the occasional detection of both HSV and HPV nucleic acid in the same tumour raises the possibility that these viruses may have an initiator-promoter relationship in the production of some tumours (McDougall et al., 1986). This area has still to be fully explored, however simplified non-isotopic techniques for the simultaneous detection of two viral genomes within single cells (Mullink et al., 1989a) theoretically offer an ideal way of investigating such questions.

\subsection{Chromosomal integration of viral DNA}

A number of viruses have the ability to integrate copies of their genomes into host cell chromosomes. While a normal event in the life-cycle of retroviruses such as HIV-I, this can also occur with several non-retroviruses including HPV, EBV and HBV. Integration not only makes possible the establishment of latent infection, but also appears to be implicated in the transformation of host cells to an immortal or malignant phenotype. Immortalized cell lines containing integrated copies of all the above viruses are available, and metaphase spreads of chromosomes from such cells have been investigated using in situ hybridization to determine the chromosomal sites of viral integration and their relationship if any, to known oncogenes or "fragile sites" (Henderson et al., 1983; Popescu and Di Paolo, 1990). The majority of such studies have employed ${ }^{3} \mathrm{H}$ labelled probes, however improvements in non-isotopic protocols have recently enabled more rapid detection of viral integration sites with improved resolution (Teo and Griffin, 1987; Lawrence et al., 1988; Lawrence et al., 1990). For example, using fluorescent detection of biotin-labelled probes, Lawrence et al. (1988) have visualized two integrated copies of EBV on chromosome 1 in metaphase spreads of the Namalwa cell line. Using probes to the different ends of the genome they compared the location of the 
integrated sequences in metaphase and interphase cells and were able to determine that the two copies lay in opposite orientation and were separated by about $340 \mathrm{~kb}$ of chromosomal DNA. Such sensitive labelling strategies combined with new techniques for chromosome karyotyping using non-isotopic probes for interspersed repetitive sequences (Boyle et al., 1990) offer the exciting possibility of viral gene localization on simultaneously-banded chromosomes.

\section{STUDIES OF VIRAL LIFE CYCLES WITHIN CELLS}

A final area of application for in situ hybridization techniques is as an aid to understanding the basic processes of infection and viral replication within individual cells. For example using fluorescent non-isotopic techniques, Lawrence et al. (1990) have detected a single bright nuclear focus of newly transcribed HIV-I RNA only 12 hours after experimental infection; its appearance preceded the accumulation of nucleic acid throughout the rest of the cell and was similar to that found in lymphocytes from HIV infected patients and in a cell line with a single integrated copy of defective HIV provirus. This suggests that the nuclear focus was derived from single or few copy viral genomes per cell, and that such an in vitro system may be useful for assessing the effects of various treatment strategies on the replicative activity of the virus (Lawrence et al., 1990). Using similar techniques, Lawrence et al. (1989) have reported the restriction of EBV RNA transcripts to a "track" extending from the interior to the periphery of infected nuclei, thus providing evidence for the non-random organization of genes and their transcripts in interphase nuclei.

The advent of the confocal laser scanning microscope for optically sectioning cells has given a major impetus to the study of intranuclear topology. The ability to generate 3-D reconstructions of the spatial arrangement of viral genomes within nuclei has been employed in a study of HeLa cells infected with adenovirus- 2 and minute virus of mouse (MVM) parvovirus (Moen $e t$ al.,1990). Using a non-isotopic fluorescent labelling system, MVM replication was localized to the nucleoli, while adenovirus-2 DNA was found in multiple non-nucleolar "replication factories" anchored along the nuclear envelope. In cells co-infected with the two viruses, MVM DNA replication was more efficient, and found to be recompartmentalized to the adenovirus replication factories. Confocal microscopy and 3-D reconstruction was also used by Harders et al. (1990) to demonstrate that potato spindle tuber viroids and their replicative intermediates were homogeneously distributed throughout the nucleoli in infected tomato leaf cell nuclei, a feature which could not have been determined by standard microscopy. 


\subsection{Ultrastructural studies}

Relatively little work has been done on the intracellular localization of viral nucleic acid at the electron microscope level. Early attempts at ultrastructural in situ hybridization with radiolabelled probes were hampered by poor resolution and long processing times. It is only quite recently with the advent of suitable electron dense, non-radioactive labels that viral genomes have been effectively localized at the ultrastructural level. Wolber et al. $(1988,1989)$ have employed a pre-embedding in situ hybridization technique to study the pathogenesis of HSV and CMV infection in cultured fibroblasts using biotinylated probes detected with streptavidin conjugated to colloidal gold spheres. CMV DNA was detected at the edge of electron dense regions in viral inclusions in fibroblast nuclei, while HSV RNA was demonstrated adjacent to the nuclear envelope. In neither case were gold clusters found bound to viral nucleocapsids, possibly because of difficulties with penetration of the gold label. PuvionDutilleul and co-workers have very successfully utilized an alternative strategy, performing in situ hybridization on thin sections of HSV infected cells embedded in Lowicryl resin (Puvion-Dutilleul and Puvion, 1989a; Puvion-Dutilleul et al., 1989). Using a biotinylated probe visualized by immunogold labelling they were able to follow the early events of infection and to demonstrate that while non-encapsidated (i.e. replicating) HSV DNA was found exclusively in the virus-induced central compartment of the nucleus, viral DNA elsewhere in the cell was always associated with capsids. Although these are preliminary findings, ultrastructural localization of viral nucleic acid represents one of the most exciting applications of the in situ hybridization technique currently being explored, with potential for investigating the processes involved in viral infection and replication at the most fundamental level.

\section{CONCLUSIONS}

The use of in situ hybridization techniques in the study of viral disease has undoubtedly been one of the most fruitful applications of the technique. It has a major role to play in the localization of viruses which evade detection by other means and has provided important data on the mechanisms of spread of certain viruses, and the processes involved in tissue damage secondary to infection. It also has considerable potential for investigating the basic biology of viral infection and replication. Several recent technological advances are likely to have a major impact on future applications of the technique; they include the use of confocal laser scanning microscopy, digital image processing techniques (which hold promise for quantification of non-isotopic hybridization signal) and automated systems for non-isotopic in situ hybridization which may facilitate "routine" laboratory diagnosis of some viral infections 
(Unger and Brigati, 1989). The use of the polymerase chain reaction "in situ" (Haase et al., 1990) is an especially exciting development, which could be of considerable benefit in studies of latent viral infections.

The broad applicability and relative simplicity of the in situ hybridization technique have resulted in its adoption by an increasing number of researchers. A word of caution should be expressed however. The detection of viral sequences in a specimen does not necessarily indicate that the virus is responsible for the disease process evident. As methods of viral detection improve it is becoming increasingly apparent that we are all host to a large population of indigenous viral flora. The challenge lies in determining which of these viral genomes have pathological significance, and how the individual's response to the virus determines the eventual outcome of infection. It is in answering these questions (rather than merely detecting the presence of viral nucleic acid) that in situ hybridization has a unique advantage, allowing as it does the correlation of viral presence with morphological and functional changes in the infected cells.

\section{ACKNOWLEDGEMENTS}

The major contributions of Drs Helen Porter and Adam Padel to several aspects of the work discussed in this chapter are acknowledged, as is the excellent technical assistance provided by Clare Riley, Mark Evans, Angela Quantrill and Andrew Heyret. Probes were generously supplied by Prof $\mathrm{H}$. zur Hausen, Heidelberg (HPV6), Dr P. Tattersall, Yale (pTY104), Dr H. Cooke, Edinburgh (pHY2.1) and Prof P. Griffiths, London (CMV HindIII fragment). Monoclonal antibodies were supplied by Dr D. Mason's laboratory, Oxford, and gold conjugates by Biocell. This work was supported by grants from the Wellcome Trust, the Oxford Regional Health Authority and the British Heart Foundation. ALM is a Nuffield Medical Research Fellow and Junior Research Fellow of New College, Oxford.

\section{REFERENCES}

Aksamit AJ, Mourrain P, Sever JL and Major EO (1985) Progressive multifocal leucoencephalopathy: investigation of three cases using in situ hybridization with JC virus biotinylated probe. Ann. Neurol. 18: 490-496.

Alexandersen S, Bloom ME, Wolfinbarger J and Race RE (1987) In situ molecular hybridization for detection of Aleutian mink disease parvovirus DNA by using strand-specific probes: identification of target cells for viral replication in cell cultures and in mink kits with virus-induced interstitial pneumonia. J Virol. 61: 2407-2419.

Ballinger ME, Rice CM and Miller BR (1988) Detection of yellow fever virus nucleic acid in infected mosquitoes by RNA:RNA in situ hybridization. Mol. Cell. Probes 2: 331-338. 


\section{In Situ Hybridization: Medical Applications}

Bamborschke S, Porr A, Huber M and Heiss WD (1990) Demonstration of herpes simplex virus DNA in CSF cells by in situ hybridization for early diagnosis of herpes encephalitis. J. Neurol. 237: 73-76.

Baskar JF, Stanat SCand Huang S (1986) Murine cytomegalovirus infection of mouse testes. J. Virol. 57: 1149-1154.

Beckmann AM, Myerson D, Daling JR, Kiviat NB, Fenoglio CM and McDougall JK (1985) Detection and localization of human papillomavirus DNA in human genital condylomas by in situ hybridization with biotinylated probes. J. Med. Virol. 16: 265-273.

Beckmann AM, Darling JR, Sherman KJ, Maden C, Miller BA, Coates RJ, Kiviat NB, Myerson D, Weiss NS and Hislop TG (1989) Human papilloma virus infection and anal cancer. Int. J. Cancer 43: 1042-1049.

Benditt EP, Barrett T and McDougall JK (1983) Viruses in the etiology of atherosclerosis. Proc. Natl. Acad. Sci. USA 80: 6386-6389.

Blum HE, Haase AT and Vyas GN (1984) Molecular pathogenesis of hepatitis B infection: simultaneous detection of viral DNA and antigens in paraffin-embedded liver sections. Lancet 2: 771-775.

Bornkamm GW, Desgranges C and Gissman L (1983) Nucleic acid hybidization for the detection of viral genomes. Curr. Top. Microbiol. Immunol. 104: 287-298.

Boyle AL, Ballard SG and Ward DC (1990) Differential distribution of long and short interspersed element sequences in the mouse genome: Chromosome karyotyping by fluorescence in situ hybridization. Proc. Natl. Acad. Sci. USA 87: 7757-7761.

Brahic M, Stowring L, Ventura P and Haase AT (1981) Gene expression in visna virus infection in sheep. Nature 292: 240-242.

Brahic M, Haase AT and Cash E (1984) Simultaneous in situ detection of viral RNA and antigens. Proc. Natl. Acad. Sci. USA 81: 5445-5448.

Brahic M and Haase AT (1989) Double-label techniques of in situ hybridization and immunocyto-chemistry. Curr. Top. Microbiol. Immunol. 143: 9-20.

Brambilla C, Tackney C, Hirschman SZ, Colombo M, Dioguardi ML, Donato MF and Paronetto F (1986) Varying nuclear staining intensity of hepatitis B virus DNA in human hepatocellular carcinoma. Lab. Invest. 55: 475-481.

Brigati DJ, Myerson D, Leary JJ, Spalholz B, Travis SZ, Fong CKY, Hsiung GD and Ward DC (1983) Detection of viral genomes in cultured cells and paraffin-embedded tissue sections using biotin-labelled hybidization probes. Virology 126: 32-50.

Burns J, Graham AK, Frank C, Fleming KA, Evans MF and McGee J (1987) Detection of low copy human papilloma virus DNA and mRNA in routine paraffin sections of cervix by non-isotopic in situ hybridisation. J. Clin. Pathol. 40: 858-864.

Burns J, Graham AK and McGee J (1988) Non-isotopic detection of in situ nucleic acid in cervix: an updated protocol. J. Clin. Pathol. 41: 897-899.

Coghlan JP, Aldred P, Haralambidis J, Niall HD, Penschow JD and Tregear GW (1985) Hybridization Histochemistry. Analyt. Biochem. 149: 1-28.

Cooke HJ, Schmidtke T and Gosden JR (1982) Characterisation of a human Y chromosome repeated sequence and related sequences in higher primates. Chromosoma 87: 491-502.

Cordell JL, Fallini B, Erber WN, Ghosh AN, Abdulaziz Z, MacDonald S, Pulford KAF, Stein $\mathrm{H}$ and Mason DY (1984) Immunoenzymatic labelling of monoclonal antibodies using immune complexes of alkaline phosphatase and monoclonal antialkaline phosphatase. J. Histochem. Cytochem. 32: 219-229.

Croen KD, Ostrove JM, Dragovic LJ and Straus SE (1988) Patterns of gene expression and 
sites of latency in human nerve ganglia are different for varicella-zoster and herpes simplex viruses. Proc. Natl. Acad. Sci. USA 85: 9773-9777.

Crum CP, Nuovo G, Friedman D and Silverstein SJ (1988) Accumulation of RNA homologous to human papillomavirus type 16 open reading frames in genital precancers. J. Virol. 62: 84-90.

Crum CP and Roche JK (1990) Molecular pathology of the lower female genital tract. The papillomavirus model. Am. J. Surg. Pathol. 14 (Suppl 1): 26-33.

Cubie HA and Norval M (1989) Detection of human papilloma viruses in paraffin wax sections with biotinylated synthetic oligonucleotide probes and immunogold staining. J. Clin. Pathol. 42: 988-991.

Eilbott DJ, Peress N, Burger H, LaNeve D, Ornstein J, Gendelman HE, Seidman R and Weiser B (1989) Human immunodeficiency virus tupe 1 in spinal cords of acquired immunodeficiency patients with myelopathy: expression and replication in macrophages. Proc. Natl. Acad. Sci. USA 86: 3337-3341.

Fleming KA (1987) In-situ hybridization - a role in clinical pathology (Editorial). J. Pathol. 153: 201-202.

Fleming KA, Evans M, Riley C, Franklin D, Morey A and Lovell-Badge R (1991) High sensitivity of non-isotopic in situ hybridization using digoxigenin labelled probes and transgenic mice. J. Pathol. 163: 154A.

Fox JD, Briggs M, Ward PA and Tedder RS (1990) Human herpesvirus 6 in salivary glands. Lancet 336: 590-593.

Gendelman HE, Narayan O, Stoskopf-Kennedy S, Kennedy PG, Ghotbi Z, Clements JE, Stanley J and Pezeshkpour G (1986) Tropism of sheep lentiviruses for monocytes: susceptibility to infection and virus gene expression increase during maturation of monocytes to macrophages. J. Virol. 58: 67-74.

Gendelmen HE, Moench TR, Narayan O, Griffin DE and Clements JE (1985) A double label technique for performing simultaneous immunocytochemistry and in situ hybridization in virus infected cell cultures and tissues. J. Virol. Meth. 11: 93-103.

Goldfarb J (1989) Leads from the MMWR. Risks associated with parvovirus B19 infection. J. Am. Med. Assoc. 261: 1406-8 1555, 1560, 1563.

Grody WW, Cheng LS and Lewin KJ (1987) In situ viral DNA hybridization in diagnostic surgical pathology. Hum. Pathol. 18: 535-543.

Grody WW, Lewin KJ and Naeim F (1988) Detection of cytomegalovirus DNA in classic and epidemic Karposi's sarcoma by in situ hybridization. Hum. Pathol. 19: 524-528.

Haase AT, Stowring L, Ventura P, Burks J, Ebers G, Tourtelotte W and Warren K (1984) Detection by hybridization of viral infection of the human central nervous system. Ann. NY Acad. Sci. 436: 103-108.

Haase AT, Walker D, Stowring L, Ventura P, Geballe A, Blum H, Brahic M, Goldberg R and O'Brien K (1985a) Detection of two viral genomes in single cells by double-label hybridization in situ and color microradioautography. Science 227: 189-191.

Haase A, Gantz D, Eble B, Walker D, Stowring L, Ventura P, Blum H, Wietgrefe S, Zupancic M, Tourtellotte W, Gibbs C J, Norrby E and Rosenblatt S (1985b) Natural history of restricted synthesis and expression of measles virus genes in subacute sclerosing panencephalitis. Proc. Natl. Acad. Sci. USA 82: 3020-3024.

Haase AT, Gantz D, Blum H, Stowring L, Ventura P, Geballe A, Moyer B and Brahic M (1985c) Combined macroscopic and microscopic detection of viral genes in tissues. Virology 140: 201-206. 
Haase A (1986) Analysis of viral infections by in situ hybridization. J. Histochem. Cytochem. 34: 27-32.

Haase AT, Retzel EF and Staskus KA (1990) Amplification and detection of lentiviral DNA inside cells. Proc. Natl. Acad. Sci. USA 87: 4971-4975.

Hadchouel M, Pasquinelli C, Fournier JG, Hugon RN, Scotto J, Bernard $O$ and Brechot $C$ (1988) Detection of mononuclear cells expressing hepatitis B virus in peripheral blood from $\mathrm{HBs} \mathrm{Ag}$ positive and negative patients by in situ hybridisation. J. Med. Virol. 24: 27-32.

Hamilton-Dutoit S, Pallesen G, Karkov J, Skinhoj P, Franzmann MB and Pedersen C(1989) Identification of EBV-DNA in tumour cells of AIDS-related lymphomas by in-situ hybridisation [letter]. Lancet 1: 554-555.

Harders J, Lukacs N, Robert-Nicoud M, Jovin TM and Riesner D (1989) Imaging of viroids in nuclei from tomato leaf tissue by in situ hybridization and confocal laser scanning microscopy. EMBO J. 8: 3941-3949.

Hawkins EP, Krischer JP, Smith BE, Hawkins HK and Finegold MJ (1990) Nasopharyngeal carcinoma in children - a retrospective review and demonstration of Epstein-Barr viral genomes in tumor cell cytoplasm: a report of the Pediatric Oncology Group. Hum. Pathol. 21: 805-810.

Henderson A, Ripley S, Heller M and Kieff E (1983) Chromosome site for Epstein-Barr virus DNA in a Burkitt tumor cell line and in lymphocytes growth transformed in vitro. Proc. Natl. Acad. Sci. USA 80: 1987-1991.

Herrington CS, Burns J, Graham AK, Bhatt B and McGee JO'D (1989a) Interphase cytogenetics using biotin and digoxigenin labelled probes II: simultaneous differential detection of two nucleic acid species in individual nuclei. J. Clin. Pathol. 42: 601-606.

Herrington CS, Graham AK, Flannery DMJ, Burns J and McGee JO'D (1990) Discrimination of closely homologous HPV types by nonisotopic in situ hybridization: definition and derivation of tissue melting temperatures. Histochem. J. 22: 545-554.

Hofler H (1987) What's new in "in situ hybridization." Pathol. Res. Pract. 182: 421-430.

Hogg JC, Irving WL, Porter H, Evans M, Dunnill MS and Fleming K (1989) In situ hybridization studies of adenoviral infections of the lung and their relationship to follicular bronchiectasis. Am. Rev. Respir. Dis. 139: 1531-1535.

Jilbert AR, Freiman JS, Gowans EJ, Holmes M, Cossart YE and Burrell C (1987) Duck hepatitis B virus DNA in liver, spleen, and pancreas: analysis by in situ and Southern blot hybridization. Virology 158: 330-338.

Jones JF, Shurin S, Abramowsky C, Tubbs RR, Sciotto CG, Wahl R, Sands J, Gottman D, Katz BZ and Sklar J (1988) T-cell lymphomas containing Epstein-Barr viral DNA in patients with chronic Epstein-Barr virus infections. N. Engl. J. Med. 318: 733-741.

Kennedy PG, Adams JH, Graham DI and Clements G (1988) A clinico-pathological study of herpes simplex encephalitis. Neuropathol. Appl. Neurobiol. 14: 395-415.

Koenig S, Gendelman HE, Orenstein JM, Canto MCD, Pezeshkpour GH, Yungbluth M, Janotta F, Aksamit A, Martin MA and Fauci A (1986) Detection of AIDS virus in macrophages in brain tissue from AIDS patients with encephalopathy. Science 233: 1089-1093.

Lawrence JB, Villnave CA and Singer RH (1988) Sensitive, high-resolution chromatin and chromosome mapping in situ: presence and orientation of two closely integrated copies of EBV in a lymphoma line. Cell 52: 51-61.

Lawrence JB, Singer RH and Marselle LM (1989) Highly localized tracks of specific 


\section{In Situ Hybridization Studies of Viral Disease}

transcripts within interphase nuclei visualized by in situ hybridization. Cell 57: 493502.

Lawrence JB, Marselle LM, Byron KS, Johnson CV, Sullivan JL and Singer RH (1990) Subcellular localization of low-abundance human immunodeficiency virus nucleic acid sequences visualized by fluorescence in situ hybridization. Proc. Natl. Acad. Sci. USA 87: $5420-5424$.

Lewandowski G, Delgado G, Holloway RW, Farrell M, Jenson AB and Lancaster WD (1990) The use of in situ hybridization to show human papillomavirus deoxyribonucleic acid in metastatic cancer cells within lymph nodes. Am. J. Obstet. Gynecol. 163: $1333-1337$.

Lewis SH, Reynolds-Kohler C, Fox HE and Nelson JA (1990) HIV-1 in trophoblastic and villous Hofbauer cells, and haematological precursors in eight-week fetuses. Lancet 335: $565-568$.

Lipkin WI, Villarreal LP and Oldstone MBA (1989) Whole animal section in situ hybridization and protein blotting: new tools in molecular analysis of animal models for human disease. Curr. Top. Microbiol. Immunol. 143: 33-54.

Lo Y-MD, Mehal WZ and Fleming KA (1988) Rapid production of vector-free biotinylated probes using the polymerase chain reaction. Nuc. Acids Res. 16: 8719.

Lohr JM and Oldstone MBA (1990) Detection of cytomegalovirus nucleic acid sequences in pancreas in type 2 diabetes. Lancet 336: 644-648.

Maitland NJ, Kinross JH, Busuttil A, Ludgate SM, Smart GE and Jones KW (1981) The detection of DNA tumor virus-specific RNA sequences in abnormal human cervical biopsies by in situ hybridization. J. Gen. Virol. 55: 123-137.

Maitland NJ, Cox MF, Lynas C, Prime S, Crane I and Scully C (1987) Nucleic acid probes in the study of latent viral disease. J. Oral. Pathol. 16: 199-211.

Masih AS, Linder JL, Shaw BWJr, Wood RP, Donovan JP, White R and Markin RS (1988) Rapid identification of cytomegalovirus in liver allograft biopsies by in situ hybridization. Am. J. Surg. Pathol. 12: 362-367.

McDougall JK, Dunn AR and Jones KW (1972) In situ hybridization of adenovirus RNA and DNA. Nature 236: 346.

McDougall JK, Fenoglio CM and Galloway DA (1980) Cervical carcinoma: detection of herpes simplex virus RNA in cells undergoing neoplastic change. Int. J. Cancer 25: 1-8.

McDougall JK, Myerson D and Beckmann AM (1986) Detection of viral DNA and RNA by in situ hybridization. J. Histochem. Cytochem. 34: 33-38.

Milde $\mathrm{K}$ and Loning T (1986) Detection of papillomavirus DNA in oral papillomas and carcinomas: application of in situ hybridization with biotinylated HPV 16 probes. J. Oral. Pathol. 15: 292-296.

Moen PTJr, Fox E and Bodnar JW (1990) Adenovirus and minute virus of mice DNAs are localized at the nuclear periphery. Nuc. Acids Res. 18: 513-519.

Moench TR (1987) In situ hybridization (review). Mol. Cell. Probes 1: 195-205.

Morey AL, Fleming KA, del-Buono R and Chandler JA (1991a) A flexible method for non-isotopic in situ labelling of multiple nucleic acid and antigenic targets in individual cells or sections. J. Pathol. 163: 159A.

Morey L, Fleming KA, Keeling JW and Porter HJ (1991b) Diagnosis and investigation of human fetal parvovirus infection by in situ hybridization combined with immunophenotyping of infected cells (submitted for publication). . 
Morey AL, Fleming KA, Ferguson D and Sutton L (1991c) Cellular features of parvovirus infection in vitro. J. Pathol. 163: 168A.

Mullink H, Walboomers JM, Raap AK and Meyer CJ (1989a) Two colour DNA in situ hybridization for the detection of two viral genomes using non-radioactive probes. Histochemistry 91: 195-198.

Mullink H, Walboomers JMM, Tadema TM, Jansen D and Mejjer CJLM (1989b) Combined immuno- and non-radioactive hybridocytochemistry on cells and tissue sections: influence of fixation, enzyme pretreatment, and choice of chromogen on detection of antigen and DNA sequences. J. Histochem. Cytochem. 37: 603-609.

Myerson D, Hackman RC, Nelson JA, Ward DC and McDougall JK (1984) Widespread presence of histologically occult cytomegalovirus. Hum. Pathol. 15: 430-439.

Myerson D (1988) In Situ Hybridizaton. In: Diagnostic Immunopathology. (R. B. Colvin, A. K. Bhan and R. T. McCluskey eds.),pp 475-498 New York: Raven Press.

Naoumov NV, Alexander GJ, Eddleston AL and Williams R (1988a) In situ hybridisation in formalin fixed, paraffin wax embedded liver specimens: method for detecting human and viral DNA using biotinylated probes. J. Clin. Pathol. 41: 793-798.

Naoumov NV, Alexander GJM, O'Grady JG, Aldis P, Portman BC and Williams R (1988b) Rapid diagnosis of cytomegalovirus infection by in-situ hybridisation in liver grafts. Lancet 1: 1361-1364.

Negro F, Bonino F, di Bisceglie A, Hoofnagle JH and Gerin JL(1989) Intrahepatic markers of hepatitis delta virus infection: a study by in situ hybridization. Hepatology 10: 916-920.

Norval M and Bingham RW (1987) Advances in the use of nucleic acid probes in diagnosis of viral diseases of man. Arch. Virol. 97: 151-165.

Orth G, Jeanteur P and Croissant O (1970) Evidence for and localization of vegetative viral DNA replication by autoradiographic detection of RNA-DNA hybrids in sections of tumors induced by Shope papilloma virus. Proc. Natl. Acad. Sci. USA 68: 1876-1880.

Ozden S, Aubert C, Gonzalez-Dunia D and Brahic M (1990) Simultaneous in situ detection of two mRNAs in the same cell using riboprobes labeled with biotin and ${ }^{35} \mathrm{~S}$. J. Histochem. Cytochem. 38: 917-922.

Padel AF, Venning VA, Evans MF, Quantrill AM and Fleming KA (1990) Human papillomaviruses in anogenital warts in children: typing by in situ hybridisation. $\mathrm{Br}$. Med. J. 300: $1491-1494$.

Patel D, Shepherd PS, Naylor JA and McCance DJ (1989) Reactivities of polyclonal and monclonal antibodies raised to the major capsid proteins of human papillomavirus type 16. J. Gen. Virol. 70: 69-77.

Peluso R, Haase AT, Stowring L, Edwards M and Ventura P (1985) A Trojan Horse mechanism for the spread of visna virus in monocytes. Virology 147: 231-236.

Perlman S, Jacobsen G and Afifi A (1989) Spread of a neurotropic murine coronavirus into the CNS via the trigeminal and olfactory nerves. Virology 170: 556-560.

Pezzella M, Rossi P, Lombardi V, Gemelli V, Mariani-Costantini R, Mirolo M, Funaro C, Moschese V and Wigzell $\mathrm{H}$ (1989) HIV viral sequences in seronegative people at risk detected by in situ hybridization and polymerase chain reaction. Br. Med. J. 298: 713-716.

Popescu NC and DiPaolo JA (1990) Integration of human papillomavirus 16 DNA and genomic rearrangements in immortalized human keratinocyte lines. Cancer Res. 50: 1316-1323. 
Porter HJ, Khong TY, Evans MF, Chan VT and Fleming KA (1988) Parvovirus as a cause of hydrops fetalis: detection by in situ DNA hybridisation. J. Clin. Pathol. 41: 381-383.

Porter HJ, Heryet A, Quantrill AM and Fleming KA (1990) Combined non-isotopic in-situ hybridization and immunohistochemistry on routine paraffin wax embedded tissue: identification of cell type infected by human parvovirus and demonstration of cytomegalovirus DNA and antigen in renal infection. J. Clin. Pathol. 43: 129-132.

Puvion-Dutilleul F and Puvion E (1989) Ultrastructural localization of viral DNA in thin sections of herpes simplex virus type 1 infected cells by in situ hybridization. Eur. J. Cell. Biol. 49: 99-109.

Puvion-Dutilleul F, Pichard E, Laithier M and Puvion E (1989) Cytochemical study of the localization and organization of parental herpes simplex virus type I DNA during initial infection of the cell. Eur. J. Cell. Biol. 50: 187-200.

Salimans MM, van de Rijke FM, Raap AK and van Elsacker-Niele AM (1989) Detection of parvovirus B19 DNA in fetal tissues by in situ hybridization and polymerase chain rection. J. Clin. Pathol. 42: 525-530.

Stevens JG (1989) Herpes simplex virus latency analyzed by in situ hybridization. Curr. Top. Microbiol. Immunol. 143: 1-8.

Stowring L, Haase AT, Petursson G, Georgsson G, Palsson P, Lutley R, Roos R and Szuchet $S$ (1985) Detection of visna virus antigens and RNA in glial cells in foci of demyelination. Virology 141: 311-318.

Syrjänen KJ (1987) Biology of human papillomavirus (HPV) infections and their role in squamous cell carcinogenesis. Med. Biol. 65: 21-39.

Syrjänen S, Cintorino M, Armellini D, delVecchio MT, Leoncini P, Bugnoli M, Pallini V, Silvestri S, Tosi P, Mantyjarvi R, et al. (1988) Expression of cytokeratin polypeptides in human papillomavirus (HPV) lesions of the uterine cervix: 1 . Relationship to grade of CIN and HPV type. Int. J. Gynecol. Pathol. 7: 23-38.

Teo CG and Griffin B (1987) Epstein-Barr virus genomes in lymphoid cells: activation in mitosis and chromosomal location. Proc. Natl. Acad. Sci. USA 84: 8473-8477.

Terry RM, Lewis FA, Robertson S, Blythe D and Wells M (1989) Juvenile and adult laryngeal papillomata: classification by in-situ hybridization for human papillomavirus. Clin. Otolaryngol. 14: 135-139.

Turtinen LW, Saltzman R, Jordan MC and Haase A (1987) Interactions of human cytomegalovirus with leukocytes in vivo: analysis by in situ hybridization. Microb. Pathog. 3: 287-297.

Unger ER and Brigati DJ (1989) Colorimetric in-situ hybridization in clinical virology: development of automated technology. Curr. Top. Microbiol. Immunol. 143: 21-31.

Vallejos H, del Mistro A, Kleinhaus S, Braunstein JD, Halwer M and Koss LG (1987) Characterization of human papilloma virus types in condylomata acuminata in children by in situ hybridization. Lab. Invest. 56: 611-615.

van der Loos CM, Volkers HH, Rook R, van den Berg FM and Houthoff H-J (1989) Simultaneous application of in situ DNA hybridization and immunohistochemistry on one tissue section. Histochem. J. 21: 279-284.

Vazeux R, Cumont M, Girard PM, Nassif X, Trotot P, Marche C, Matthiessen L, Vedrenne C, Mikol J, Henin D, et al. (1990) Severe encephalitis resulting from coinfections with HIV and JC virus. Neurology 40: 944-948.

Venables PJ, Teo CG, Baboonian C, Griffin BE and Hughes R (1989) Persistence of Epstein-Barr virus in salivary gland biopsies from healthy individuals and patients with Sjogren's syndrome. Clin. Exp. Immunol. 75: 359-364. 
Weiss LM, Movahed LA, Warnke RA and Sklar J (1989) Detection of Epstein-Barr viral genomes in Reed-Sternberg cells of Hodgkin's disease. N. Engl. J. Med. 320: 502-506.

Wolber RA and Lloyd RV (1988) Cytomegalovirus detection by nonisotopic in situ DNA hybridization and viral antigen immunostaining using a two-color technique. Hum. Pathol. 19: 736-741.

Wolber RA, Beals TF, Lloyd RV and Maassab H (1988) Ultrastructural localization of viral nucleic acid by in situ hybridization. Lab. Invest. 59: 144-151.

Wolber RA, Beals TF and Maassab H (1989) Ultrastructural localization of herpes simplex virus RNA by in situ hybridization. J. Histochem. Cytochem. 37: 97-104.

Wolf BC, Martin AW, Neiman RS, Janckila AJ, Yam LT, Caracansi A, Leav BA, Winpenny R, Schultz DS and Wolfe HJ (1990) The detection of Epstein-Barr virus in hairy cell leukemia cells by in situ hybridization. Am. J. Pathol. 136: 717-723.

Yamashiroya HM, Ghosh L, Yang R and Robertson ALJ (1988) Herpesviridae in the coronary arteries and aorta of young trauma victims. Am. J. Pathol. 130: 71-79. 